\title{
Plasmid-Encoded Multidrug Resistance: A Case study of Salmonella and Shigella from enteric diarrhea sources among humans
}

\author{
Clarence Suh Yah \\ School of Chemical and Metallurgical Engineering, University of the Witwatersrand, Johannesburg, South Africa. Private Bag 3, \\ Wits 2050, South Africa, Telephone: +27117177597 , Fax: +27117177599 , Mobile phone: +27763004836 \\ *E-mail: yahclar@gmail.com or clarence.yah@wits.ac.za
}

\begin{abstract}
Salmonellosis and shigellosis are significant and persistent causes of diarrheal diseases among humans in developing countries. With that in mind, the current study investigates the occurrence of plasmid-encoded multidrug resistances in Salmonella and Shigella from diarrheal cases among humans. The isolates were characterized by serotyping, antimicrobial-susceptibility testing, transfer experiments and curing. The extended spectrum $\beta$-lactamase (ESBL) was detected by the double disc diffusion synergy test (DDST). A significant number of the plasmid-encoded multidrug resistant (PEMDR) Salmonella and Shigella isolates were found to harbour transferable plasmid genes resistant to antibiotics like ampicillin, chloramphenicol, trimethoprim-sulfamethoxazole, ceftriaxone, cefuroxime and to a lesser extent to ciprofloxacin and ofloxacin. The conjugative R-plasmids-encoded extendedspectrum $\beta$-lactamase also showed resistances to cephalosporins (ceftriaxone and cefuroxime) and ampicillin. Curing experiments showed chromosomal resistances to varied antibiotics. The findings confirmed the presence of PEMDR in Salmonella and Shigella strains as a suitable adaptation to a changing antibiotic environment. The results therefore suggest the limited use of the commonly prescribed/or third generation cephalosporins as an empirical treatment of multidrug resistant Salmonella and Shigella because this may affect therapeutic outcomes.
\end{abstract}

Key terms: Salmonella-Shigella, plasmid-encoded, multidrug-resistant.

\section{INTRODUCTION}

Salmonella and Shigella infections represent a major health problem worldwide, particularly in the developing countries where they are recognized as the most frequent cause of morbidity and mortality (David \& Frank, 2000; Mahbubur et al., 2007; Abdel et al., 2008). Mortality is highly associated with infants under one year of age (South Australia Department of Health, 2008). The impact of lives lost, together with the high costs to local public health care systems, makes prevention and control a priority (Mahbubur et al., 2007; Yah et al., 2007a). The infections caused by the two pathogens have been associated with diarrhea, but the severity of the diarrhea varies with the pathogen. Generally Shigella causes bloody diarrhea in stool known as bacillary dysentery, while Salmonella induced non-bloody gastroenteritis.

Antibiotics resistant Salmonella and Shigella are of global concern because they affect both developed and developing countries due to increased international travel (David \& and Frank, 2000; Dubois et al., 2007). These concerns have been further reinforced in recent years by the emergence of antimicrobial resistance among the major groups of the enteric pathogens. The presence of antibiotic-resistant bacteria from hospitalized patients throughout the world has been documented (Yah et al., 2007b). Studies with Salmonella and Shigella are of particular relevance because these species can occupy multiple niches, including human and animal hosts (Martin et al., 1996; Levy, 1997; Khan, 2006). In addition, Escherichia coli strains can efficiently exchange genetic material with pathogens such as Salmonella, Shigella, Yersinia, and Vibrio species (Levy, 1997; Tauxe et al., 1987). Reports have shown that the resistance of gastroenteric Salmonella and Shigella strains to these antimicrobial agents is in large part due to the production of extended-spectrum $\beta$-lactamases (ESBLs) encoded on plasmids, as well as on the chromosome, as reported by David and Frank (2000), Rodríguez et al (2004) and Yujuan et al (2006). To ensure an appropriate treatment of salmonellosis and shigellosis in Nigeria, a four-province survey were conducted to determine the plasmid-encoded multidrug resistant (PEMDR) serotypes of Salmonella and Shigella isolates between November 2007 and November 2008. The study was also undertaken to 
determine the trends of the predominant serotypes and antibiotic sensitivity pattern of the PEMDR serotypes of Salmonella and Shigella isolates in order to predict their future trends.

\section{METHODS}

Sample collection and isolation of organism

One thousand two hundred and seventy five (1275) diarrheal stool samples were collected from patients with diarrhea from November 2007 to November 2008, to examine for plasmidencoded multidrug resistant (PEMDR) serotypes of Salmonella and Shigella isolates. One hundred and fifty three (153) were resistant to 3 or more classes of antibiotics. As well, 201 stool samples were collected from non-diarrheal healthy individuals as a control group. Fecal samples were cultured onto MacConkey and on Salmonella and Shigella agars. The isolates were further identified biochemically by the standard methods (Kelly et al., 1985) and Shigella was grouped serologically by slide agglutination with specific antisera (Denka Saiken, Tokyo, Japan). The Salmonella isolates were further identified by the API20E system (bioMérieux) and were serotyped using Salmonella-specific $\mathrm{O}$ and $\mathrm{H}$ antigens by the slide agglutination test.

\section{Beta-lactamase production Test}

The $B$-Lactamases were visualized by staining with nitrocephin $0.2 \mathrm{mg} / \mathrm{mL}$ (Oxoid). The $\beta$-lactamase production was inferred when the broth turned red within 30 minutes of addition of the reagent. The colonies of the test bacteria were picked from overnight Mueller Hinton Agar plates and inoculated into sterile Mueller Hinton Broth and incubated at $37{ }^{\circ} \mathrm{C}$ for 24 hours. Three to four drops of nitrocephin solution (Calbiochem, Germany) were added to each broth culture for color change within 30 minutes. Positive results change color from yellow to red with hydrolysis. Nitrocephin is a chromogenic cephalosporin that changes color from yellow to red with hydrolysis (Cheesbrough, 2000).

\section{Antibiotic Susceptibility Testing:}

The E-test method (AB Biodisk) was used to screen for the antibiotic susceptibility patterns of the Salmonella and Shigella isolates. The minimum inhibitory concentration (MIC) (susceptibility test) was determined in accordance with the manufacturer's guidelines (AB Biodisk, Sweden). The $0.5 \mathrm{McF}$ arland standard isolates were inoculated onto Mueller Hinton agar plates by swabbing evenly in three directions. The E-test strip (obtained from the refrigerator at $4^{\circ} \mathrm{C}$ was applied to each plate with sterile forceps with the lowest concentration toward the centre of the agar plate. The plates were then incubated at 30 to $35{ }^{\circ} \mathrm{C}$ for 24 hours. The E-test MIC values were read directly from the E-test strip MIC scale. The following antibacterial agents: ofloxacin (Ofl), ciprofloxacin (Cip), cefuroxime (Cef), ceftriaxone (Ce), gentamicin $(\mathrm{Gn})$, trimethoprimsulfamethoxazole (Txm-Sal), ampicillin (Am) and chloramphenicol (Chl) were used. The concentration gradient of each antimicrobial agent on the E-test strips was 0.016 to $256 \mu \mathrm{g} / \mathrm{ml}$, with the exception of ciprofloxacin and ofloxacin, for which the gradient ranged from 0.002 to $32 \mu \mathrm{g} / \mathrm{ml}$. The susceptibility range, as defined by $\mathrm{AB}$ Biodisk Sweden were: ofloxacin ( $\leq 2, \mathrm{I}=4$ and $\mathrm{R} \geq 8$ ), ciprofloxacin ( $\leq 1, \mathrm{I}=2$ and $\mathrm{R} \geq 4$ ), cefuroxime, ceftriaxone and ampicillin $(S \leq 8, I=16$ and $R \geq 32)$, gentamicin $(S \leq 4$, $\mathrm{I}=8$ and $\mathrm{R} \geq 16$ ), trimethoprim-sulfamethoxazole $(S \leq 2$ and $R \geq 4)$ and chloramphenicol $(S \leq 8, I=16$ and $R \geq 32$ ) where $S$ = sensitivity, $I=$ intermediate and $\mathrm{R}=$ resistance. The Production of extendedspectrum $\beta$-lactamase (ESBL) was detected using the double disk synergy test (DDST) according to CLSI (2005). The DDST was performed by placing disks of cefuroxime $30 \mu \mathrm{g}$, ceftriaxone $30 \mu \mathrm{g}$ and ampicillin $20 \mu \mathrm{g}$ each at a distance of $30 \mathrm{~mm}$ away (centre to centre) from a disk containing augmentin (amoxicillin $20 \mu \mathrm{g}$ and clavulanic acid $10 \mu \mathrm{g}$ ). The Salmonella and Shigella strains were considered to be ESBL producing when the area around any of the test antibiotic discs showed an increased zone of inhibition by the synergy of augmentin (Tzelepi et al., 2000 and Xiaofei et al., 2006)

\section{Curing of Plasmid-Encoded Multidrug Resistant (PEMDR) serotypes}

Curing of the strains was carried out using the modification of Yah et al (2007b). The Salmonella and Shigella cells were cured by treating them with $10 \%$ sodium dodecyl sulfate (SDS). The colonies were then sub-cultured onto Mueller Hinton agar (Difco Laboratories, Detroit, Mich USA) plates and test run for their respective antibiotic sensitivity patterns and ESBL as previously described. Some of the bacteria were sensitive, while some were resistant. Absence of growth in Mueller Hinton agar was indicative of plasmids-mediated resistance while growth in Mueller Hinton agar was indicative of chromosomemediated.

Conjugation of Plasmid-Encoded Multidrug Resistant (PEMDR) serotypes

Conjugation experiments were performed as described by Yukata et al (2004) using the Escherichia coli strains 
obtained from the Nigerian Institute for Medical Research (NIMR), Lagos, as the recipient. The donors and recipients-plasmid -free - rifampicin/ cefotaxime resistant strains were incubated on Mueller Hinton broth (Difco Laboratories Detroit, Mich USA) at $37{ }^{\circ} \mathrm{C}$ for 18 hours. The transconjugants were selected on MacConkey agar medium supplemented with $200 \mu \mathrm{g} / \mathrm{ml}$ rifampicin and $2 \mu \mathrm{g} / \mathrm{ml}$ cefotaxime (Daiichi Pharm. Co. Ltd, Japan) to inhibit the growth of the donor and recipient respectively. The transconjugants were re-streaked onto fresh selective culture plates and their identities were re-confirmed on the basis of the biochemical methods. The ESBL and antibiotics resistance patterns were re-confirmed on Mueller Hinton Agar. The Birnboim and Doly (1979) method was employed for screening plasmids (rapid alkaline extraction) of donors and transconjugants. The DNA of the plasmids was then electrophoresed on $0.8 \%$ agarose gel and stained with $14 \mu \mathrm{l}$ of ethidium bromide. The DNA was then photographed with a Polaroid camera and viewed using UV trans-illumination. The molecular weights and distances were determined using standard methods according to Meyers et al (1976) and Birnboim and Doly (1979) with a standard DNA molecular weight marker II (0.12-23.1kbp) of bacteriophage lambda HindIII (Roche Diagnostic $\mathrm{GmbH})$.

STATISTICAL ANALYSIS

The significance of differences in the proportions of antimicrobial resistance and of the relative prevalence of each Salmonella and Shigella species was determined by the Chi-Square Test. The twotailed test was applied.

\section{RESULTS}

The emergence of PEMDR Salmonella and Shigella is a significant evolution in antimicrobial resistances. Antimicrobial-susceptibility testing showed that Salmonella and Shigella isolates were highly resistant to ampicillin, chloramphenicol, trimethoprimsulfamethoxazole, gentamicin, ceftriaxone, cefuroxime and, to a lesser extent, ciprofloxacin and ofloxacin (Table 1). The results also showed that only $12 \%$ of both Salmonella and Shigella species samples were resistant to 3 or more antibiotics.

The extended spectrum $\beta$-lactamase (ESBL) was detected by the double disc diffusion synergy test (DDST) as shown in Table 2. The result indicated that out of 97 Salmonella species, $10.3 \%$ and $15.5 \%$ were resistant to $\mathrm{Ce}+\mathrm{AMC}$ and $\mathrm{Cef}+\mathrm{AMC}$, respectively, while $24.7 \%$ was resistant to $\mathrm{Am}+\mathrm{AMC}$. On the other hand, out of 56 Shigella species, 30.4\% and $12.5 \%$ were resistant to $\mathrm{Ce}+\mathrm{AMC}$ and Cef $+\mathrm{AMC}$, respectively, while $32.1 \%$ to $\mathrm{Am}+\mathrm{AMC}$ (Table 2).

The frequency of PEMDR gene transfer from donors to recipients of the Salmonella and Shigella species ranged from $2.1 \times 10^{-2}-1.1 \times 10^{-6}$, with an average of 2 plasmids per cell (Table 3 ).

The transfer resistant genes were found in $70 \%$ of the transconjugants tested, while 30\% were not successfully transferred. The molecular weights of

Table 1

The percentage (\%) occurrence of resistant Salmonella and Shigella to antibiotics via E.test strips.

\begin{tabular}{|c|c|c|c|c|c|c|c|c|c|}
\hline \multirow[t]{2}{*}{ Type of Isolate } & \multirow[t]{2}{*}{ No. of isolates } & \multicolumn{8}{|c|}{$\%$ resistant Salmonella and Shigella antibiotics } \\
\hline & & $\mathrm{Ce}$ & Cef & $\mathrm{Am}$ & Ofl & Cip & Txm-Sal & Chl & Gn \\
\hline Salmonella species & 97 & $27(27.8 \%)$ & $23(23.7 \%)$ & $52(53.6 \%)$ & $18(18.6 \%)$ & $8(8.2 \%)$ & $21(21.6 \%)$ & $51(52.6 \%)$ & $32(33 \%)$ \\
\hline Shigella species. & 56 & $21(37.5 \%)$ & $18(32.1 \%)$ & $32(57.1 \%)$ & $6(10.7 \%)$ & $10(17.9 \%)$ & $25(44.6 \%)$ & $38(67.8 \%)$ & $24(42.9 \%)$ \\
\hline
\end{tabular}

Key: Ofloxacin (Ofl), Ciprofloxacin (Cip), Cefuroxime (Cef), Ceftriaxone (Ce), Gentamicin (Gn), Trimethoprim-Sulfamethoxazole (Txm-Sal), Ampicillin (Am) and Chloramphenicol (Chl).

Table 2

The percentage (\%) production of ESBL of Salmonella and Shigella via the DDST.

\begin{tabular}{lcccc}
\hline Isolates & No. of isolates & \multicolumn{2}{c}{ \% resistance spectrum of Salmonella and Shigella to $\beta$-lactam drugs } \\
\cline { 3 - 5 } & & Ce+AMC & Cef +AMC & Am+AMC \\
\hline Salmonella Species & 97 & $10(10.3 \%)$ & $15(15.5 \%)$ & $24(24.7 \%)$ \\
Shigella species & 56 & $17(30.4 \%)$ & $7(12.5 \%)$ & $18(32.1 \%)$ \\
\hline
\end{tabular}

Key: Cefuroxime (Cef), Ceftriaxone (Ce), Ampicillin (Am) and Augmentin (AMC); Extended Spectrum -Lactamase (ESBL) and Double Disk Synergy Test (DDST) 
both the donors and transconjugants of the plasmids ranged from $\leq 1.1 \mathrm{kbp}-\geq 4.7 \mathrm{kbp}$ (Table 3), while those of the cured cells were $\geq 4.7 \mathrm{kbp}$.

A significant number of the plasmid-encoded multidrug resistant (PEMDR) Salmonella and Shigella isolates were found to contain transferable plasmids, conferring resistance to ampicillin, chloramphenicol, trimethoprim-sulfamethoxazole, ceftriaxone, cefuroxime and, to a lesser extent, ciprofloxacin and ofloxacin (Table 3). The conjugative R-plasmidsencoded extended-spectrum $\beta$-lactamase showed resistance to cephalosporins (ceftriaxone and cefuroxime) and ampicillin. Curing experiment results showed that resistance genes were also ESBL chromosomally mediated (Table 3).

\section{DISCUSSION}

Since the discovery of the magic bullet by Alexander Fleming in 1929, it has been very difficult not only to save millions of lives, but also to save billions of dollars that are lost annually due to drug resistance research. According to the current findings it was observed that a highly varied antibiotics resistance of Salmonella and Shigella species exist among the antibiotics tested (Table1). The result also showed the prevalence of Shigella and Salmonella slightly is higher than those earlier reported by Yah et al (2007b) two years ago. The increase in prevalence observed in this study is probably due to lack of education and public awareness on the hygienic conditions resulting from the pathogens. This unprecedented medical situation can considerably escalate and accelerate the selection pressure for the diversification and dissemination of antibiotics resistant mutant in any community of concern. According to $\mathrm{Xu}$ et al (2007), the adult human intestine contains trillions of bacteria, representing hundreds of species and thousands of subspecies and little is known about the selective pressures that have shaped and are shaping their resistance to antibiotics. These findings are further supported by previous reports by Yah et al (2007b) and Yah et al (2008), in which they showed that laboratory results described from diarrheal sources and pattern of antibiotics usage have escalated into highly resistant bacterial isolates emerging in developing countries. However, the misuse of antibiotics in clinical practice in most developing countries has provided selective pressure favoring resistant bacterial strains. Therefore, inappropriate use of antibiotics increases the risk for selection and dissemination of antibiotic-resistant bacteria, which are often placed at a competitive advantage (Yah et al., 2008). Our results show that quinolones are the drug of choice for the treatment of shigellosis and salmonellosis infections. This is because they showed the lowest resistance pattern among the antibiotics tested. This confirms the earlier reports of Yah et al (2007b) that quinolones are the best diarrheagenic antibiotics after oral rehydration therapy (ORS). As well, these antibiotics are a new generation; very expensive and very few patients can afford them. Their misuse, however, is still in its infancy. This is because clinicians tend to prescribe low and affordable antibiotics to their patients, which can lead to selective pressure. The fluoroquinolones (Ofl, Cip) are bactericidal and selectively inhibit bacterial DNA gyrase enzymes, thereby preventing DNA production. Gentamicin $(\mathrm{Gn})$, one of the commonest, oldest and least expensive antibiotics worked quite well against the isolates in this study. This might be due to the mode of administration via the parental route, therefore reducing abuse and misuse as compared to other older and less expensive common antibiotics.

Studies have also shown that resistance to broadspectrum $\beta$-lactams is highly mediated by extendedspectrum $\beta$-lactamase (ESBL) enzymes, increasing the world health problem in clinical settings (Yujuan \& Ling, 2006; Valverde et al., 2008). In the present study, $24.7 \%$ of Salmonella and $32.1 \%$ of Shigella were ESBL producers against ampicillin, respectively. The results showed that $10.3 \%$ of the cefuroxime and $15.5 \%$ ceftriaxone were resistant to Salmonella isolates, while $30.4 \%$ and $12.5 \%$, respectively, to Shigella. The results also showed that both Salmonella and Shigella were both beta-lactamase mediated chromosomally, as shown in Table 3. Generally ESBLs are not always carried on the bacterial chromosome, but rather can mostly be found on bacterial plasmid (Zaki, 2007; Valverde et al., 2008).

However, several studies have shown that bacterial plasmids can harbor different plasmid genes, as well as having the ability to transfer replica of themselves to other bacteria (Yah et al., 2007a; $\mathrm{Xu}$ et al., 2007). Therefore, by analyzing the trends of beta lactamase producing strains of various Shigella and Salmonella have shown the significant impact of plasmids resistant strains of Shigella and Salmonella (Valverde et al., 2008). These findings are of special importance because Shigella and Salmonella are at present the predominant species in so many developing countries. These changes have been associated with efficient dispersion of specific clones and plasmids harboring $b a_{\mathrm{ESBL}}$ genes (Schjørring et al., 2008). The reports by Schjørring et al (2008) have also shown that antimicrobial treatment provides a major advantage to bacteria harboring antimicrobial resistant genes. Therefore, bacteria acquire most of their genetic material from distantly related bacteria species. Such gene-swapping is the way most environmental and pathogenic bacteria pick up antibiotic resistance. To maintain effective 


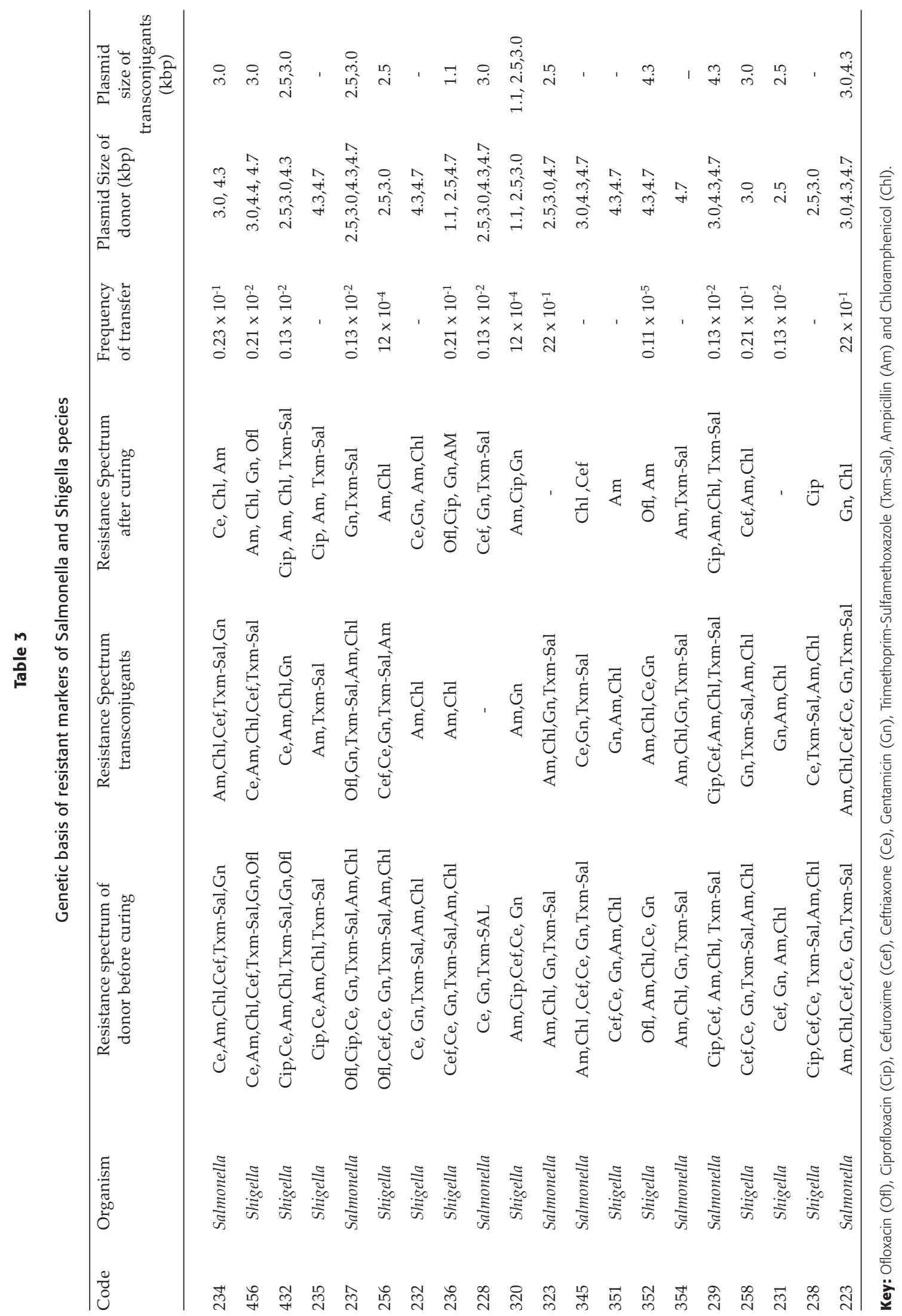


treatments and the development of new antibiotics, it is important to monitor the rates and patterns of lateral gene transfer (Yah et al., 2007a; Jacobsen et al., 2007; Wiles et al., 2000).

The plasmid-borne $\beta$-lactamases are also competent enough to hydrolyze $\beta$-lactam antibiotics, as well as the mechanism of resistance to $\beta$-lactam agents among gram-negative bacteria. The existence of ESBL on theses isolates was the principal stimulus to the development of the compounds that inhibit $\beta$-lactamases (Lima et al., 2007). According to our findings, ampicillin-resistant bacteria were the most predominant and the highest producer of $\beta$-lactamase against the isolates. These were similar to earlier findings reported by Lima-Bittencourt et al (2007) when they assayed for multiple antimicrobial resistances in Enterobacteriaceae isolates from pristine freshwater and found that most of the ampicillin-resistant bacteria were harbouring $\beta$-lactamase enzymes.

The present results also show very high resistance rates among the isolated Salmonella and Shigella to the beta-lactam antibiotics. Salmonella and Shigella species were highly resistant to cefuroxime and ceftriaxone cephalosporins, which are commonly used to treat various nosocomial infections and are frequently used as the first line of drugs for patients admitted to hospitals in Nigeria. ESBL production appears to be the major mechanism of cefuroxime and ceftriaxone resistance to strains of Salmonella and Shigella. This was shown by the double-disc screening test method.

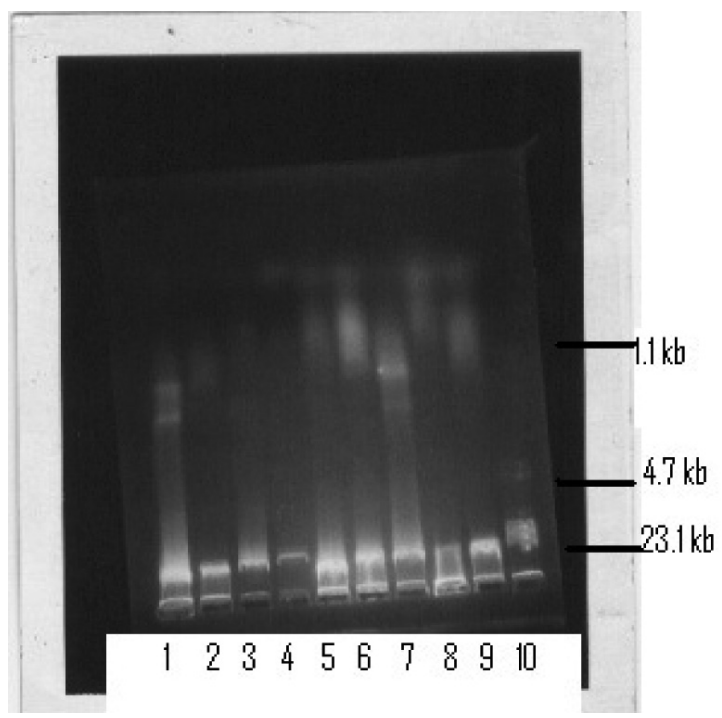

Figure 1: Plasmids DNA of donor of SalmonellaShigella strains stained with ethidium bromide according to Birnboim an Doly (1979). Line $10=$ Standar bacteriophage lambda DNA. lines 1-9 are plasmids DNA bands of test isolates.

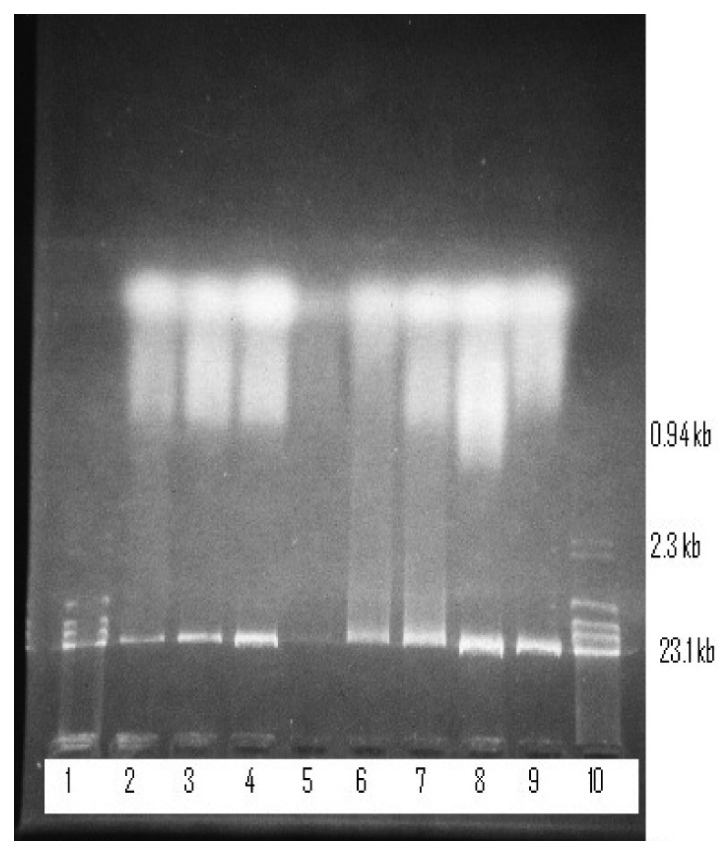

Figure 2: Gel electrophoresis of cured Salmonella and Shigella strains stained with ethidium bromide chromosomal DNA bands. Lines 1 and 10 are Standar DNA markers of lambda Phage Hill III while lines 2 to 9 are DNA of test isolates.

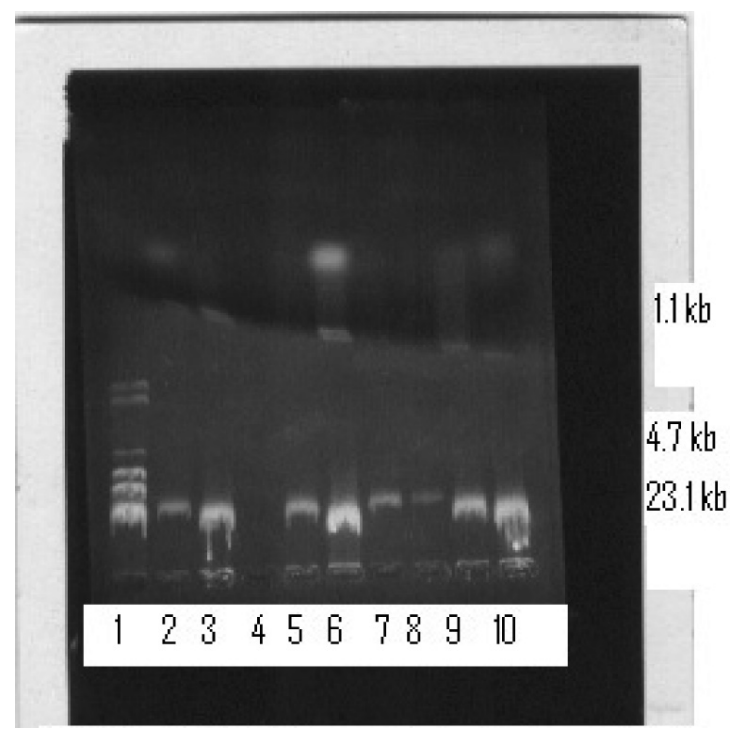

Figure 3: Plasmids DNA of transconjugants of Salmonella-Shigella strains with ethidium bromide Birnboim an Doly (1979). Line $1=$ Standar bacteriophage lambda DNA fragment. lines 2-10 are plasmids DNA bands of test isolates. 
The high ESBL production therefore showed that Salmonella and Shigella are competing with Klebsiella species as ESBL producers and care should be taken when handling such isolates. According to Schjørring et al (2008) Klebsiella pneumoniae is an excellent colonizer of the intestine and is extremely promiscuous with respect to the transferability of its numerous plasmids. Moreover, antimicrobial treatment enhances the selection of resistant strains and results in an increase in the resistance gene pool, which ultimately raises the risk of the spreading resistance gene-swapping mechanisms. These enhance the chances of Salmonella, Shigella and other gastrointestinal tract gram-negative isolates as strong ESBL producers. According to earlier reports by Spanu et al (2002) and Zaki (2007), many ESBL producers carry other genes that confer resistance to other antimicrobial agents such as aminoglycosides and fluoroquinolones. This confirms the present studies where PEMDR carries genes for other antibiotics apart from beta-lactam drugs as shown in Table 3.

The findings confirmed the presence of PEMDR in Salmonella and Shigella strains, as well as the suitable adaptation of PEMDR in the changing antibiotic environment. Apart from that, there was a decrease in the susceptibility to quinolones in PEMDR and ESBL producing Salmonella-Shigella strains.

\section{CONCLUSION}

This study therefore reveals that PEMDR Salmonella and Shigella are among the bacteria commonly implicated in diarrhea cases. They are now among the important nosocomial agents since they are relatively high in diarrhea cases in developing countries. Therefore, the issue of antisepsis should be taken seriously. In severe cases, the combination of antibiotic-chemotherapy may be the most appropriate method in the management of such diarrheagenic cases, rather than the traditional single antibiotics therapy. As well, there is a need for an antibiotic policy in hospitals as an additional effort towards reducing the menace of PEMDR development in Salmonella, Shigella and other pathogens.

\section{ACKNOWLEDGEMENT}

I am grateful to the management and staff of the Nigerian Institute of Medical Research (NIMR), Yeba Lagos, especially Dr SI Smith for the facilities provided for this work, and the authorities of the teaching hospitals for their assistances. Thanks also go to Associate Professor Tatfeng YM and Professor Agbonlahor DE of the Biotechnology Unit, Lahor Research Laboratories, Benin City, Nigeria, for their support.

\section{REFERENCES}

ABDEL HH, HAWAS S, EL-DAKER M, EL-KADY R (2008) Extended-spectrum -lactamase producing Klebsiella pneumoniae in neonatal intensive care unit. J Perinat 28: 685-690.

BIRNBOIM HC, DOLY J (1979) A rapid alkaline extraction procedure for screening recombinant DNA plasmids. Nucleic Acids Res 7: 1513-1523.

CHEESBROUGH M (2000) District Laboratory Practice Manual in Tropical Countries. Part 2.Cambridge University Press. Pp: 178-179.

CLSI (2005) Performance Standards for Antimicrobial Susceptibility Testing. Fifteenth Informational Supplement M100-S15. Wayne, PA: Clinical and Laboratory Standards Institute.

DAVID LW, FRANK GR (2000) Surveillance of antimicrobial resistance in Salmonella, Shigella and Vibrio cholerae in Latin America and the Caribbean: A collaborative project. Can J Infect Dis 11(4): 181-186.

DUBOIS V, PARIZANO MP, CORINNE A, LAURE C, BEZIAN MC, CLAUDINE Q (2007) High genetic stability of integrons in clinical isolates of Shigella spp. of Worldwide Origin. Antimicrob Agents Chemother 51 (4): 1333-1340.

JACOBSEN L, WILCKS A, HAMMER K et al (2007) Horizontal transfer of tet (M) and erm (B) resistance plasmids from food strains of Lactobacillus plantarum to Enterococcus faecalis $\mathrm{JH} 2-2$ in the gastrointestinal tract of gnotobiotic rats. FEMS Microbiol Ecol 59: 158-66.

KHAN MKR, THUKRAL SS, GAIND R (2006) Modifgied Double Disk Synergy Test for the detection of extended spectrum $\beta$-lactamase in AmpC $\beta$-lactamase-producing Proteus mirabilis. Ind J Med Microbio 26(1): 58-61.

KELLY MT, BRENNER J, FARMER JJ (1985) Enterobacteriaceae. In: LENNETTE EH, BALOWS A, HAUSLER J, JR, SHADOMY HJ (eds). Manual of Clinical Microbiology, $4^{\text {th }}$ ed. Washington, DC. ASM pp: 263-277.

LEVY SB (1997).Antibiotic resistance: an ecological imbalance. Ciba Found Symp 207: 1-9: Discussion 9-14.

LIMA-BITTENCOURT CI, CURSINO L, GONÇALVESDORNELAS H, PONTES DS, NARDI RMD, CALLISTOM, CHARTONE-SOUZA E, NASCIMENTO AMA (2007) Multiple antimicrobial resistance in Enterobacteriaceae isolates from pristine freshwater. Genet Mol Res 6 (3): 510-521.

MAHBUBUR R, SHEREEN S, HARUNUR R, SHAMS EL A, BAQUI AH, SIDDIQUE AK, NAIR GB, SACK DA (2007) Increasing spectrum in antimicrobial resistance of Shigella isolates in Bangladesh: Resistance to azithromycin and ceftriaxone and decreased susceptibility to ciprofloxacin. J Health, Pop Nutr 25(2): 158-167.

MARTIN GM, STEVEN AM, RONALD NJ (1996) detection of extended-spectrum $\beta$-lactamase (ESBL)-producing strains by the Etest ESBL screen. J Clin Microbio 34(8): 1880-1884.

MEYERS JA, SANCHEZ D, ELWELL LP, FALKOWS S (1976) Simple agarose gel electrophoretic method for the identification and characterization of plasmids deoxyribonucleic acid. J Bacteriol 127: 1529-1537.

RODRÍGUEZ MM, POWER P, RADICE M, VAY C, FAMIGLIETTI A, GALLENI M, AYALA JA, GUTKIND G (2004) Chromosome-encoded CTX-M-3 from Kluyvera ascorbata: a possible origin of plasmid-borne CTX-M-1derived cefotaximases. Antimicrob Agents Chemother 48: 4895-4897.

SCHJØRRING S, CARSTEN S, KAREN AK (2008) Transfer of antimicrobial resistance plasmids from Klebsiella pneumoniae to Escherichia coli in the mouse intestine. J Antimicrob Chemother 2008 62(5): 1086-1093.

SPANU T, LUZZARO F, PERILLI M, AMICOSANTE G, TONIOLO A, FADDA G (2002) Occurrence of extended- 
spectrum beta lactamases in members of the family Enterobacteriaceae in Italy: implications for resistance to beta-lactams and other antimicrobial drugs. Antimicrob Agents Chemother. 46: 196-202.

SOUTH AUSTRALIA DEPARTMENT OF HEALTH (2008) Health in all Policies. Public Health Bulletin 5 (1): 1-55.

TAUXE RV, CAVANAGH TR, COHEN ML (1987). Interspecies transfer in vivo producing an outbreak of multiply resistant shigellosis. J Infect Dis 160: 1067-70.

TZELEPI E, GIAKKOUPI A, SOFIANOU D, LOUKOVA V, KEMEROGLOU A, TSAKRIS A (2000) Detection of extended-spectrum beta-lactamases in clinical isolates of Enterobacter cloacae and Enterobacter aerogenes. J Clin Microbiol 38: 542-546.

VALVERDE A, GRILL F, TERESA MC, PINTADO V, FERNANDO B, RAFAEL C, COBO J (2008) High rate of intestinal colonization with extended-spectrum-lactamaseproducing organisms in household contacts of infected community patients. J Clin Microbio 46(8): 2796-2799.

WILES T, J HEJNA, GOSNELL M, YU C AND KENNEDY V (2000) Determining beta-lactam resistance among gramnegative Isolates in the phoenix ${ }^{\mathrm{TM}}$ automated Microbiology System. As presented at the 10th European Congress of Clinical Microbiology and Infectious Diseases (ECCMID), May 2000.

XIAOFEI J, ZHE Z, MIN L, DANQIU Z, FEIYI R, YUAN L (2006) Detection of extended-spectrum $\beta$-lactamases in clinical isolates of Pseudomonas aeruginosa. Antimicrob Agents Chemother. 50(9): 2990-2995.
XU, J, MICHAEL AM, RUTH EL, CATHERINE AL, MICAH $\mathrm{H}$, ERIC CM, BERNARD $\mathrm{H}$, PEDRO MC, PATRICK $\mathrm{M}$, PHILIPPE L, HOLLAND C, ANDREW VB, KYUNG K, ROBERT SF, LUCINDA AF, SANDRA WC, RICHARD KW, ROBIN DK, JEFFREY IG. (2007) Evolution of symbiotic bacteria in the distal human intestine. PLoS Biology 5 (7): 1574-1586.

YAH SC, EGHAFONNA NO, ORANUSI S, ABOUO AM (2007a) Widespread plasmids resistance transfers genes among Proteus species in diabetic wounds of patients in the Ahmadu Bello University Teaching Hospital (ABUTH) Zaria. Afr J Biotechnol 6(15): 1757-1762.

YAH SC, CHINEYE HC, EGHAFONA NO (2007b) Multi antibiotics-resistance plasmid profile of enteric pathogens in pediatric patients from Nigeria. Biokemistri 19(1): 35-42.

YAH SC, YUSUF OE, EGHAFONA NO (2008) Pattern of antibiotic usage by adult populations in the city of Benin, Nigeria. SRE 3 (3): 081-085.

YUJUAN J, LING JM (2006) CTX-M-producing Salmonella spp. in Hong Kong: an emerging problem. J Med Microbiol 55: 1245-1250.

YUKATA S, NAOHIRO S, YOHEI D, YOSSHICHIKA A (2004) Escherichia coli producing CTX-M-2 B- Lactamase in cattle. Japan Emerg Infect Dis 10(1): 69-75.

ZAKI MES (2007) Extended spectrum $\beta$-lactamases among gram-negative bacteria from an Egyptian pediatric hospital: a two-year experience. J Infect Develop Count 1(3): 269-274. 